\title{
Geology and Petroleum Systems of the Offshore Benin Basin (Benin)
}

\author{
C. Kaki ${ }^{1 *}$, G.A.F. d'Almeida ${ }^{1}$, N. Yalo ${ }^{1}$ and S. Amelina ${ }^{2}$ \\ 1 University of Abomey-Calavi, 01 BP 526 Cotonou (Benin) \\ 2 Beninese Company of Hydrocarbon (CBH) 01 BP 8060 Cotonou (Benin) \\ e-mail: kaki_christophe@yahoo.fr - almeidafranck@hotmail.com - yalonicaise@yahoo.fr - amelinasuanne@yahoo.fr \\ * Corresponding author
}

\begin{abstract}
Résumé - Géologie et système pétrolier du bassin offshore du Benin (Benin) - Cet article résume l'évolution tectono-sédimentaire et le système pétrolier du Bassin Offshore du Bénin (BOB). Conformément à l'évolution structurale, la succession stratigraphique de ce bassin a été divisée en quatre séquences : anté-rift (allant jusqu'à la fin du Jurassique); rift (Néocomien-Crétacé inférieur); transitionnelle (Cénomanien-Santonien) et post-rift (Maastrichtien-Holocène). Un seul système pétrolier d'âge Crétacé supérieur a été identifié avec certitude dans ce bassin. Les roches mères de ce système contiennent du kérogène de Type II-III, avec un COT (Carbone Organique Total) moyen de 2,9 \% . L'huile est produite à partir des faciès gréseux de la formation d'Abeokuta. Les données actuelles d'exploration et les caractéristiques géochimiques des sables bitumineux qui affleurent par endroits dans la partie continentale de la baie du Dahomey mettent en évidence l'existence d'un autre système pétrolier d'âge Crétacé inférieur (Néocomien à Albien) dans ce bassin.
\end{abstract}

\begin{abstract}
Geology and Petroleum Systems of the Offshore Benin Basin (Benin) - This paper summarizes the tectonosedimentary development and petroleum system of the Offshore Benin Basin $(O B B)$. In accordance with structural development, the stratigraphic succession of this basin was divided into 4 sequences: pre-rift (up to Late Jurassic); rift (Neocomian to Lower Cretaceous); transitional (Cenomanian to Santonian) and post-rift (Maastrichtian-Holocene) sequences. Only one Upper Cretaceous petroleum system is well known within this basin. Source rocks of this system contain Type II-III kerogens with a TOC (Total Organic Carbon) average of 2.9\%. Oil is produced from sandstone facies within Abeokuta formation. Currently exploration data and geochemical characteristics of bituminous sands which outcrop in some onshore areas of the Dahomey Embayment point to the existence of another petroleum system of Lower Cretaceous age (Neocomian to Albian) in this basin.
\end{abstract}




\section{INTRODUCTION}

With an area of some $40000 \mathrm{~km}^{2}$, the Offshore Benin Basin (OBB) belongs to the Benin Coastal Basin, one of the coastal basins of the "Dahomey Embayment" (Fig. 1).

The Romanche transform fault and chain fractures zones delimit the Dahomey Embayment which was formed during the opening of Equatorial Atlantic starting in the Late Jurassic and continuing into the Cretaceous (Almeida and Black, 1967; Le Pichon and Hayes, 1971; Burke et al., 1971; Mascle, 1976; Omatsola and Adegoke, 1981; Mascle et al., 1988; Tucker, 1992; Chierici, 1996; Eagles and Konig, 2008; Moulin et al., 2010). Seismic and bore hole data show that sedimentary fill within the Basin is more than $3500 \mathrm{~m}$ thick. The stratigraphy of the OBB has been discussed by various workers (Hessouh et al., 1994; Kaki et al., 2001; Brownfield and Charpentier, 2006) and several classification schemes have been proposed. In the OBB, only one petroleum system was presently clearly identified. This system is referred to here as the Cretaceous petroleum system. The maximum extent of this system coincides with the boundaries of the Embayment and the minimum extent of the system is defined by the area extent of fields of the eastern Dahomey Embayment (Benin and western Nigeria). Currently, most of this petroleum is in fields on the continental shelf or in waters less than 2000 meters deep.

According to the significant increased interest and exploration activity in the northern Gulf of Guinea, this paper aims to define the geology and the petroleum systems of the Offshore Benin Basin (OBB). The results of this study can be useful for companies in target to infer the hydrocarbon potential of the basin and hence make an assessment of the basin resources.

\section{TECTONOSTRATIGRAPHIC DEVELOPMENT}

The tectonic framework along the continental margin of the Dahomey Embayment is controlled by Cretaceous fracture zones expressed as trenches and ridges in the deep Atlantic. The marginal basins of the Dahomey Embayment formed at the culmination of Late Jurassic to Early Cretaceous tectonic activity that was characterized by both block and transform faulting superimposed across an extensive Paleozoic basin during breakup of the African, North American and South American paleocontinents (Almeida and Black, 1967; Le Pichon and Hayes, 1971; Mascle, 1976; Omatsola and Adegoke, 1981; Mascle et al., 1988; Guiraud and Maurin, 1992; Bumby and Guiraud, 2005; Eagles and Konig, 2008; Aslanian et al., 2009; Moulin et al., 2010).

\subsection{Calibrated Seismic Sections of Seme Field}

The tectono-sedimentary stages which have characterized the development of the OBB were recognized using essentially data from Seme oilfield (Fig. 2). The Seme oilfield comprises two main oil-bearing structures named North Seme and South Seme, separated approximately by $4 \mathrm{~km}$.

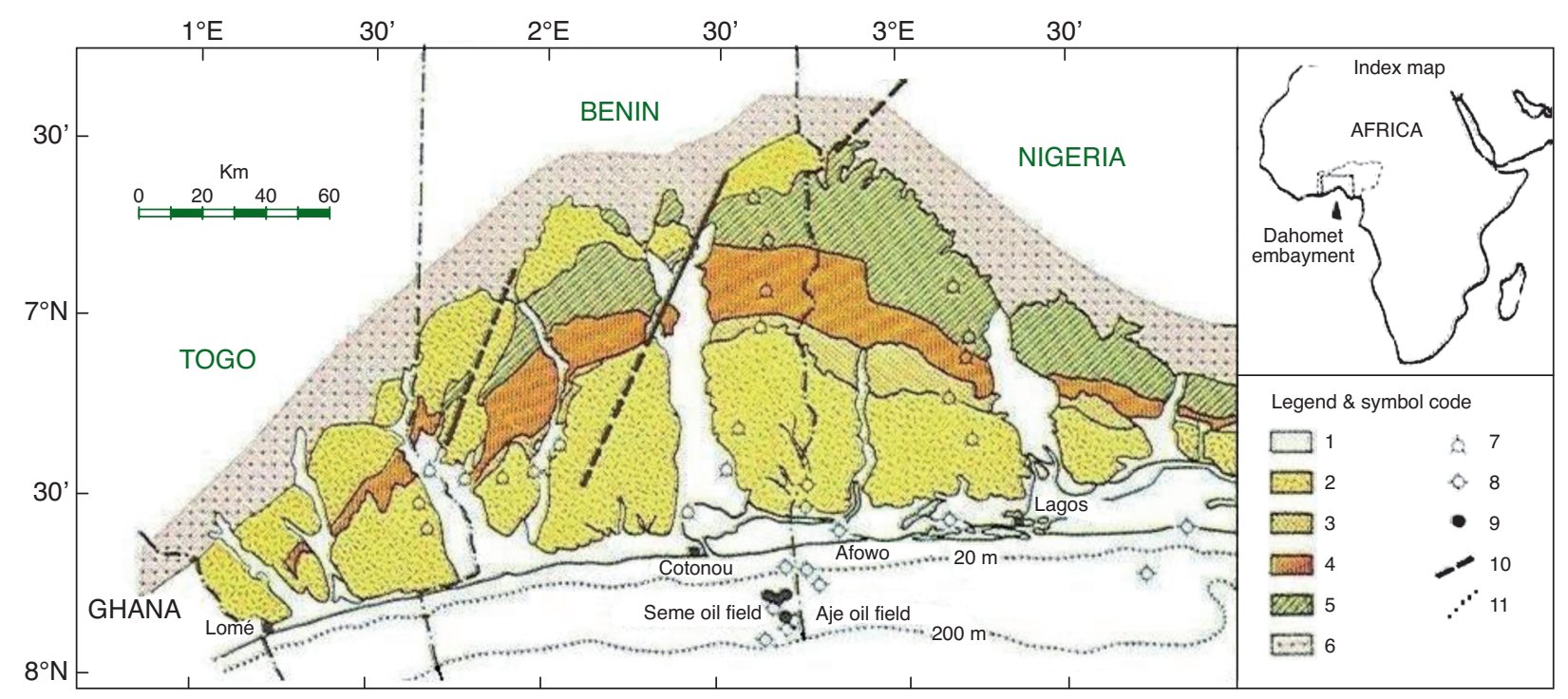

Figure 1

Localization of the Benin Coastal Basin within the "Dahomey Embayment" (Hessouh et al., 1994, modified). 1-6: Formations: 1- Alluvium (Recent); 2- Benin-Ijebu (Pleistocene/Upper Miocene); 3- Oshoshun (Middle Eocene); 4- Imo shale (Lower Eocene/Paleocene); 5- Araromi shale \& Turonian sandstone (Upper Cretaceous); 6- Pre-Cambrian crystalline basement; 7- Core hole or water well; 8- Dry well; 9- Oil well; 10- Faults; 11- Water depth contour. 


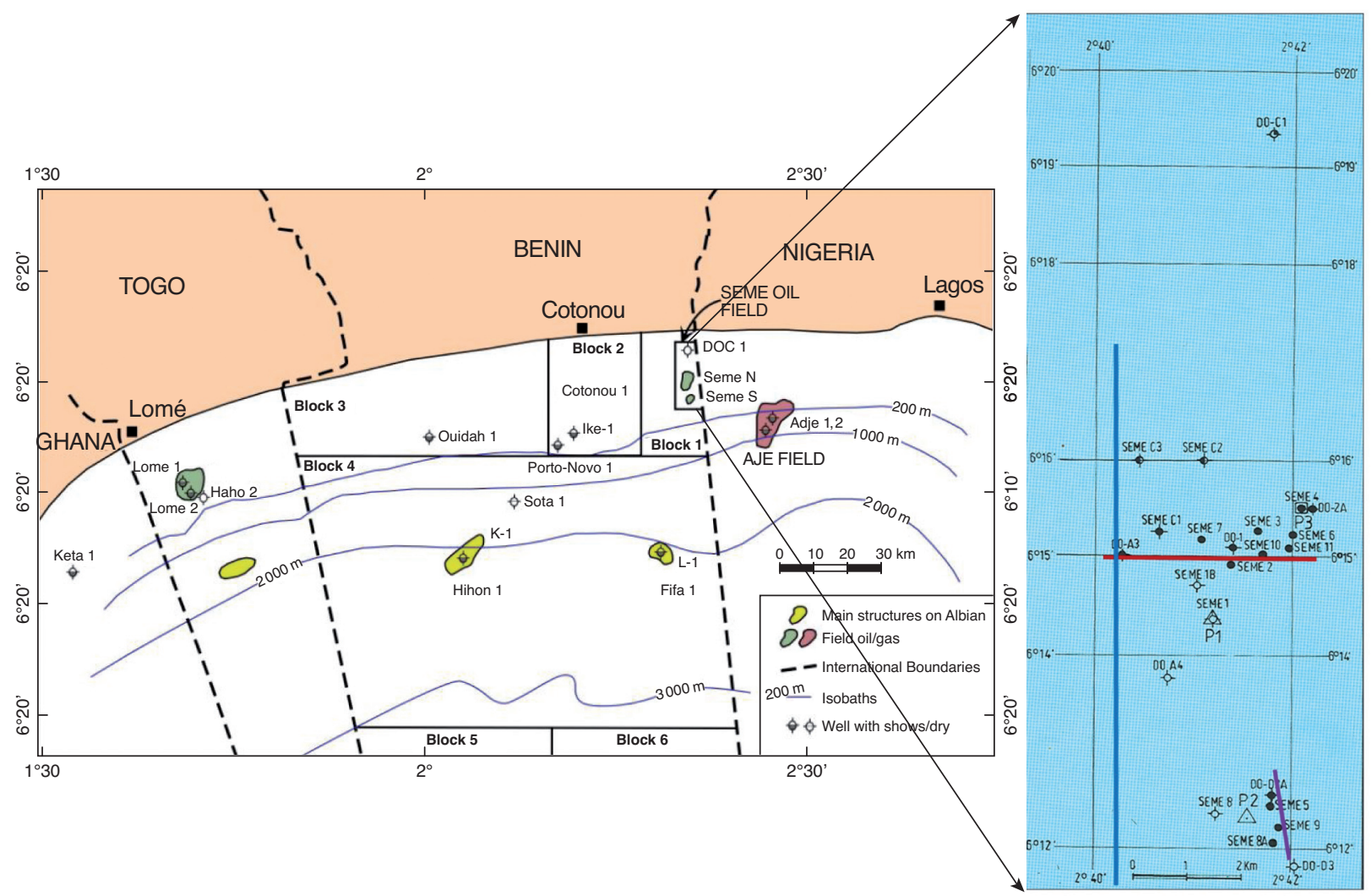

Figure 2

Dahomey Embayment with localization of Seme oilfield and used seismic sections. (Red line: line 2 990; violet line: line BE 8 378-410; blue line: line BE 8 262-315).

Petrographic analyses of cores samples confirm that rocks within the embayment are almost exclusively clastics and in a gross sense, mirror the increasing separation of the continents representing a graduation from terrestrial at the base, through shallow marine, deep marine (with restrictive bottom circulation) to open deep marine. Stratigraphy and tectonosedimentary stages of the OBB were acknowledged using calibrated seismic sections. In this paper, two seismic sections extracted respectively from lines 2990 and BE 8378-410 acquired (see Fig. 2) in that order within the northern and southern structures of the Seme field and were used to show facies geometry within the basin (Fig. 3, 4).

The calibration process gives possibility to identify on various seismic sections the reflectors which represent the main stratigraphy unconformities and some formations boundaries. Calibration results are gathered in Table 1 .

Consequently, it was possible to identify the sequences types, the surfaces which draw up the boundaries of each of them and understand the geometry of sedimentary bodies within the Offshore Benin Basin. The proposed model of geoseismic section for line BE 8 262-315 is shown in Figure 5.
TABLE 1

Seismic horizons and their stratigraphic correspondents

\begin{tabular}{c|c}
\hline H2 & Mid-Miocene unconformity \\
\hline H3 & Base Miocene unconformity \\
\hline Intra-Imo FM & Eocene unconformity \\
\hline H4 & Top Araromi fm \\
\hline Intra-Araromi FM & Mid-Maestrichtian unconformity \\
\hline H5 & Maestrichtian unconformity \\
\hline H6 & Top Abeokuta sandstone \\
\hline H7 & Early Cenomanian sandstone \\
\hline H8 & Mid Albian unconformity \\
\hline H9 & Mid Cretaceous unconformity \\
\hline Deep marker & Base of syn-rift Ise (?)
\end{tabular}

\subsection{Tectono-Sedimentary Stages}

Interpreted seismic sections as well as geoseismic model of a section of line BE 8 262-315 (Hessouh et al., 1994) gave 
WEST

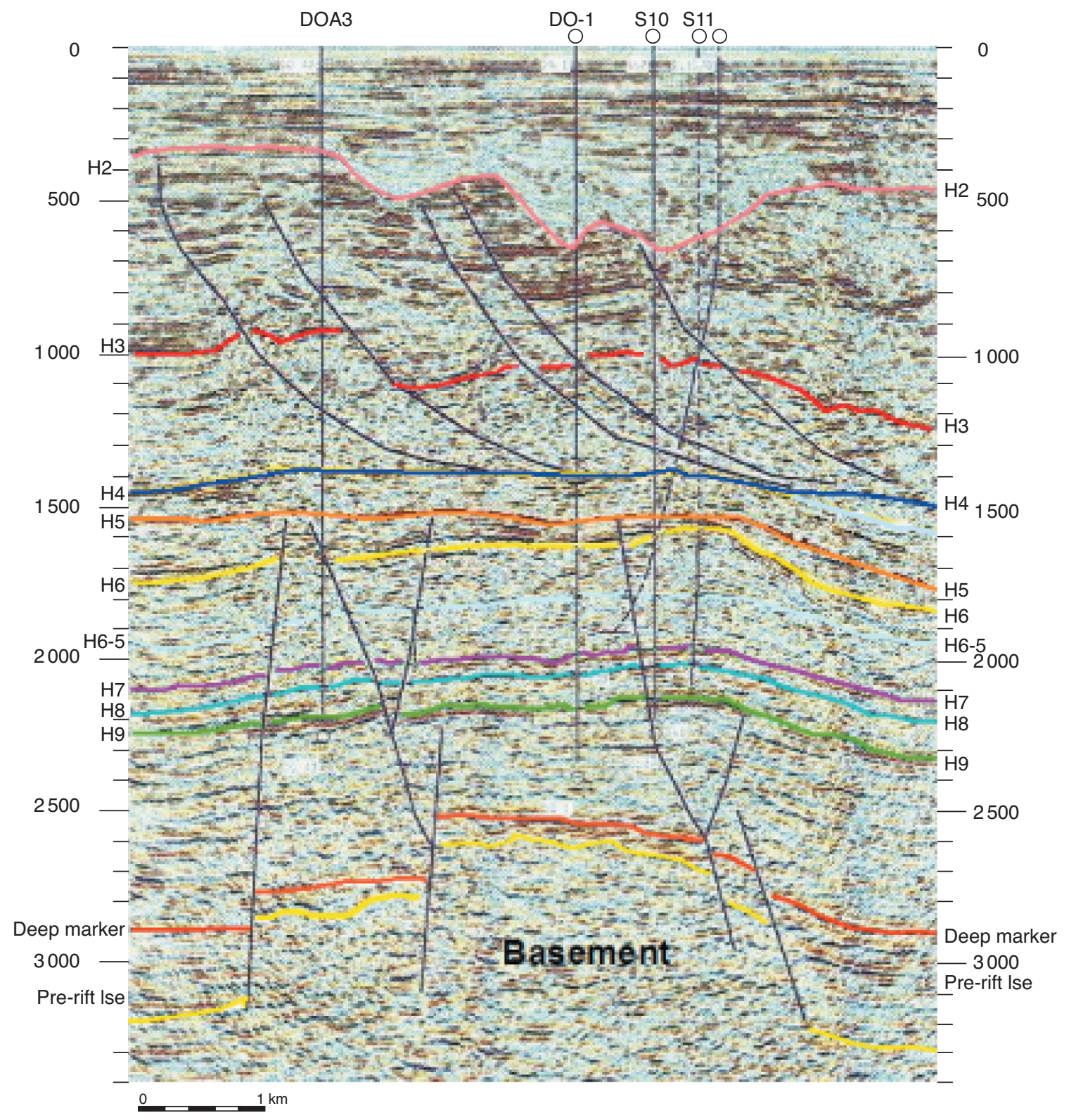

Figure 3

Calibrated 3D seismic section extracted from line 2990 showing seismic marker horizons (within Northern Structure).

possibility to understand that the Dahomey Embayment region has undergone a complex history, which is generally divided into four tectono-sedimentary stages: pre-rift (up to Late Jurassic), syn-rift (Neocomian to Lower Cretaceous), transitional (Cenomanian to Santonian) and post-rift (Maastrichtian to Holocene). These 4 stages are referred to as intracratonic, rift, transitional and drift stages by many authors (Slansky, 1962; Billman, 1976; Tucker, 1992; Hessouh et al., 1994; Chierici, 1996; Kaki et al., 2001;
Brownfield and Charpentier, 2006). Thus, the drift stage was preceded by a Late Cretaceous transitional period which extends from Cenomanian to Santonian.

\section{Pre-Rift Stage (up to Late Jurassic)}

The pre-rift rocks in the Dahomey Embayment are represented by the lower part of the Ise formation (Kogbe and Mehes, 1986; Jan Duchene, 1998; Kaki et al., 2001; Brownfield and Charpentier, 2006). In the Offshore Benin Basin drilling has 


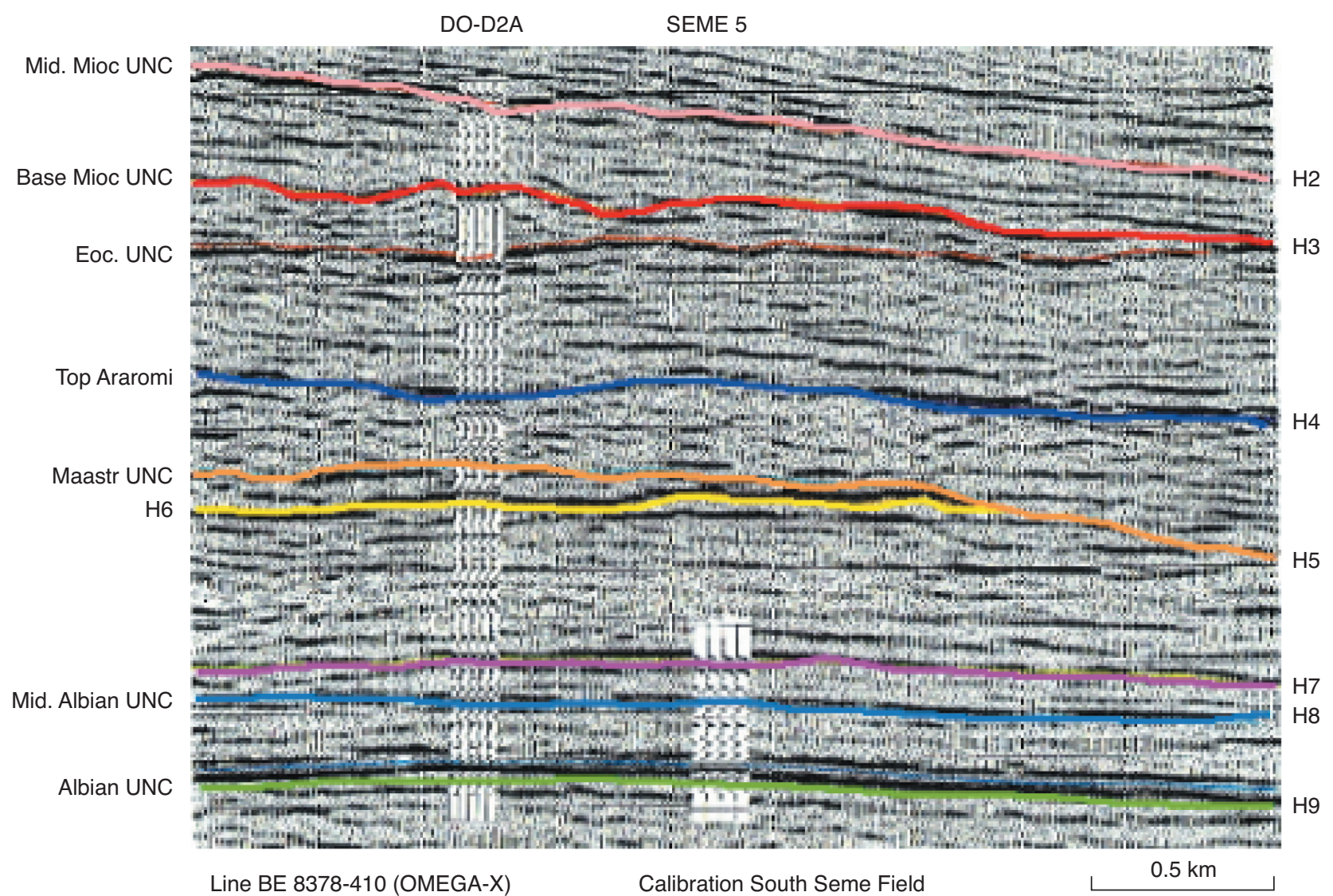

Figure 4

Calibrated 2D seismic section extracted from line BE 8 378-410 (within Southern structure).

not reached the lower section of the Ise formation but seismic data indicate that it directly overlies basement rocks and is present on tilted basement blocks and in a series of grabens and half grabens (Fig. 3).

On calibrated 3D seismic section extracted from line 2990 acquired in the northern structure of the Seme, the lower boundary of Ise formation is the seismic marker named horizon H10 and its upper boundary named "Deep marker" represents the end of the pre-rift stage in the OBB. Indeed, beneath the "Deep marker" Horizon (see Fig. 3), we can observe other continuous subparallel seismic reflectors that indicate the existence of pre-rift sediments below this seismic frontier which form a sheet above the older basement rocks. In a regional setting, the "Deep marker" Horizon (in comparison with Keta Basin of Eastern Ghana), which is an unconformity separating the pre-rift and the syn-rift sequences, is interpreted as a sill of volcanic intrusives (basalt or dolerite) which indicate in time the beginning of rifting process and initial block faulting in the Dahomey Embayment. However, the pre-rift stage is interpreted to be largely a period of erosion and non deposition in the Dahomey Embayment. The eroded sediments could be transported westward because they are most likely preserved as the Jurassic pre-rift rocks in the Tano and Ivory Coast Basins (Brownfield and Charpentier, 2006). In Aje oilfield of Western Nigeria (Fig. 1) seismic data indicate that the thickness of the entire Ise formation is about $2000 \mathrm{~m}$. Since any drilled well doesn't reach the base of this formation, the datation of his lower part is uncertain.

\section{Syn-Rift Stage: Neocomian - Lower Cretaceous}

Although it was considered that the syn-rift stage began during the Neocomian in the Dahomey Embayment (Billman, 1976; Hessouh et al., 1994; Kaki et al., 2001); data on the age of volcanic intrusives associated with initial block faulting in Eastern Ghana indicate that faulting started no later than the Late Jurassic in the Dahomey Embayment (MacGregor et al., 2003; Brownfield and Charpentier, 2006). Orientation of the intrusives indicates that the initial fracturing and graben formation were subparallel to the present coastline (Eagles and Konig, 2008; Moulin et al., 2010). Block faulting and graben 


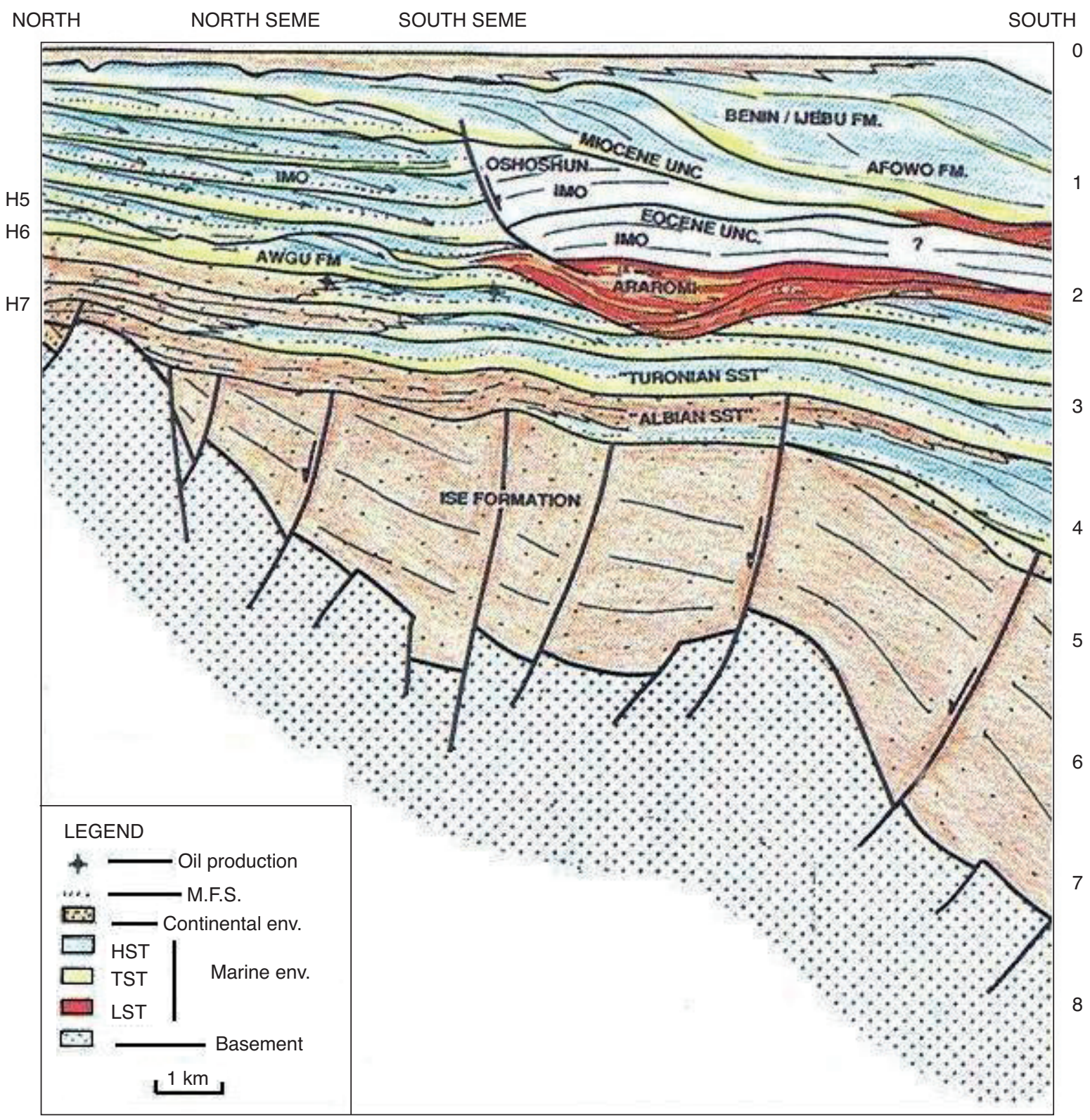

Figure 5

Geoseismic section of line BE 8 262-315 (Hessouh et al., 1994 modified).

filling characterized the initial tectonic stage, followed by transform or extensional faulting.

In Seme field, the oldest syn-rift rocks are represented by the Neocomian part of the Ise formation. The upper part of this formation was encountered in the following wells DO-1, DO-D2A, Seme 9 and Seme 10 (see Fig. 2) and only few meters (less than $250 \mathrm{~m}$ ) was drilled on geologist request. The lithology consists of sandstone, shale and conglomerate deposited in fluvial, lacustrine and deltaic environments (Dumestre, 1985; Elvsborg and Dalode, 1985; MacGregor et al., 2003). Sandstones are white to light grey, medium to coarse, unsorted, conglomeratic, quartzic and well indurate with abundant kaolinite, carbonate cement and high content of feldspar, mica and chlorite. The shales are grey, brown, fissile and hard (Kaki et al., 2000; Brownfield and Charpentier, 2006). No fossils have been recovered. Datation based on spore and pollen was provided but was unsuccessful because this part of the formation is much damaged (Amelina, 2006). Owing to limited drilling data, we presently consider that the part of Ise formation encounter in the Aje 
field and defined as Neocomian age, represents the uppermost part of this formation and may be equivalent to the Lower Cretaceous Sekondi formation of Keta Basin. The upper part of the Ise formation contains lacustrine algae (Haack et al., 2000; Brownfield and Charpentier, 2006) and is unconformably overlain by the "Albian sandstone". The "Albian Sandstone" is interpreted as representing a transgressive phase with the sea advancing in a tilted and eroded rift basin after deposition of the Ise formation (see Fig. 5). The lithology of this unit is predominantly sandstone with frequent shaley and dolomitic thin beds, which distinguishes it from the overlying unit. The sandstones are white to grey to dark brown, fine to coarse grained, fair to poor sorting, feldspathic and micaceous. A maximum of $455 \mathrm{~m}$ was penetrated in well DO-D2A while $403 \mathrm{~m}$ was encountered in DO-1. In DO-C1 well, the "Albian Sandstone" overlain the crystalline basement and its thickness reach $234 \mathrm{~m}$.

Deposition of the "Albian sandstone" occurred in an off lapping siliciclastic sedimentation cycle that prograded southwestward. During the earliest Cretaceous, the basin underwent gradual subsidence, block faulting and graben filling followed by extensional faulting. Syn-sedimentary faulting occurred in response to variable rates of subsidence and sediment supply. The interplay of subsidence and supply rates resulted in deposition of discrete depobelts when further crustal subsidence of the basin could no longer be accommodated, the focus of sediment deposition shifted seaward, forming a new depobelt. Each depobelt is a separate unit that corresponds to a break in regional dip of the offshore basin and is bounded landward by growth faults. Aptian and Albian rocks are characterized by marine sandstone and shales with some organicrich black shales, coarse sandstone and minor limestone (Kjemperud et al., 1992; Kaki et al., 2001). The oldest marginal marine strata are in the upper Albian and the lack of evaporites in the Lower Cretaceous section indicates that in the Dahomey Embayment the syn-rift sediments were deposited in a humid equatorial climate. Graben filling continued until the middle of the Cenomanian, when uplift of the region brought about extensive erosion and peneplanation. In OBB, shallow marine environment is predominant for the upper part of the Unit and fluvial environment is predominant for the lower part below H8 seismic horizon (see Fig. 5).

The lower limit of transgressive "Albian Sandstone" is the seismic marker named Horizon 9 (H9) and its upper boundary (seismic marker H7) represents the end of the syn-rift stage in the OBB. The end of the syn-rift stage is delineated by a major unconformity, which separates it from the transitional rocks of the uppermost Cenomanian to Santonian. This major unconformity is also readily recognized in the Brazilian marginal basins, which supports the interpretation that the two continents were close to one another during the Early Cretaceous and that their geologic histories were similar during that time (Almeida and Black, 1967; Eagles, 2008; Moulin et al., 2010).

\section{Transitional Stage: Cenomanian to Santonian}

The transitional Cenomanian to Santonian stage, in the Offshore Benin Basin and Dahomey Embayment, was influenced by transform and/or extensional faulting and also was affected by deformation that took place during the Santonian in the Benue Trough to the east (Elvsborg and Dalode, 1985). These episodes of tectonic activity resulted in the development of the Senonian unconformity in the coastal Benin basin (Fig. 5, 6). During this stage, Abeokuta and Awgu formations were deposited. The Abeokuta formation which includes two stratigraphic units is present over the entire OBB and, in places, directly overly crystalline basement. The "Abeokuta formation" is assigned to a Cenomanian-Turonian age. Cenomanian shales unit gather the oldest deposits of the transitional stage. The "Turonian sandstone" unit unconformably overlies the Cenomanian unit. At this stage, a steep shelf began to develop during the Cenomanian along the continental margin of the Northern Gulf of Guinea. Scientists speculated that several south-flowing ancient rivers (from some basins like Oni, Ogun, Yema, Oueme, Mono and Volta) supplied clastics to the continental margin of the Dahomey Embayment prior to Santonian uplift in the Northeast and their actual orientation. These rivers would have drained extensive areas to the north during the early post-rift period and deposited large amounts of clastics sediment during the Cenomanian to Maastrichtian now represented by the "Turonian sandstones" or the equivalent Abeokuta formation (Elvsborg and Dalode, 1985; MacGregor et al., 2003; SAPETRO, 2010). The lithology of "Turonian sandstone" consists in gray to white coarse-grained, poorly sorted sandstone interbedded with thin shale beds overlying a shale and siltstone sequence deposited as a reworked fan delta in a marginal marine to inner shelf environment. The Maastrichtian Unconformity cuts into the formation in the eastern most part of the shelf in the vicinity of the Seme field, while the Mid Miocene Unconformity only affects the formation beyond the shelf edge (Elvsborg and Dalode, 1985). The depocenter is located in the eastern part of the basin, where thicknesses are as much as $1000 \mathrm{~m}$ and the unit thins to the north and west. Because the continental shelf is steep and was subjected to several low stands along the continental margin, conditions favored the deposition of detached, deep water sandstone units, ponded turbidite sands and clastics fans (Fig. 5). The depositional conditions are from prograding fan deltas with possible marine processes in the upper part. Fluvial environment is predominant for lower part of the unit, below H6.5 seismic horizon. The upper boundary of Abeokuta sandstones is usually picked with the influx of immature, medium and coarse predominantly non-calcareous sandstone. It is materialized by the seismic marker H6. The lower limit is the $\mathrm{H} 7$ (see Fig. 5).

The Coniacian Awgu formation which is present over most of the Benin offshore unconformably overlies the "Turonian sandstone" and its distribution is controlled by the 
Senonian unconformity. The formation, consisting of dark-gray calcareous shale interbedded with calcareous siltstone and fine-grained sandstone which was deposited in an anoxic marine environment below the Senonian unconformity (Fig. 5). The age of the formation is Lower Senonian (Coniacian) to Maastrichtian age and it is limited at the top by Senonian Unconformity and at the base by the seismic marker H6.

\section{Post-Rift Stage: Maastrichtian to Recent}

The post-rift stage rocks in the Dahomey Embayment consist predominantly of marine Cenomanian to Holocene sandstones, shales and minor carbonate rocks deposited in alternating regressions and transgressions (Dumestre, 1985; Chierici, 1996; Kjemperud et al., 1992; MacGregor et al., 2003; Hessouh et al., 1994; Kaki et al., 2001) that resulted in several Late Cretaceous and Tertiary unconformities (Fig. 5, 6). In general, continental-margin tectonics of the region post-rift stage was driven by thermal subsidence. Five Maastrichtian to Holocene post-rift stratigraphic units, being separated by unconformities, have been identified in the Benin Basin (Fig. 6):

- the Maastrichtian to Paleocene Araromi shale subdivided into an upper and lower member. The boundary between the upper Araromi and lower Araromi members is announced by change in shale color. The upper Araromi formation is of Paleocene age while the lower Araromi formation is of Maastrichtian age. This formation comprises black to dark laminated carbonaceous shales with abundant pyrite and pyritised microfauna. Limestone layers occur frequently. The Araromi formation was deposited immediately above the Senonian unconformity. His upper limit is the seismic marker named (H4). Araromi shales are clearly deep sea (Upper bathyal) shales deposited in an anaerobic restricted bottom circulation environment;

- the Paleocene to Eocene Imo shale which is conformably overlying the Araromi formation and over larger shelf area conformably underlies the Oshoshun formation. The formation consists of light greenish to bluish, grey to dark grey, non calcareous, firm to moderately hard shales with stringers of dark grey, microcrystalline limestone. The age of the formation is restricted to Early Eocene (Hessouh et al., 1994; Kaki et al., 2001; Brownfield and Charpentier, 2006; Nton et al., 2009). The Imo formation is present on the entire shelf offshore Benin and attains a thickness of approximately $400 \mathrm{~m}$ in the Seme area. The formation has a reduced thickness in a westward direction. In some areas on the shelf, younger formations have eroded into Imo formation. The upper limit of Imo formation is set where the greenish shale become abundant and confirmed by GR decrease at the same point. The Imo formation has been deposited in an upper bathyal to outer sublittoral marine, well-oxygenated environment;
- the Eocene Oshoshun formation is assigned to offshore sequence of marine shales and sandy shales of Middle Eocene age containing abundant phosphatic material (Billman, 1976). The formation consists of sandy, varied colored and phosphatic claystone grading to siltstone. The Oshoshun formation appears to be present all over the shelf area, although eroded to the shelf break by the Mid Miocene Unconformity (H2) and locally in the vicinity of seme field. The depositional environment is interpreted as marine, outer sublittoral and well oxygenated (Amelina, 2006);

- the Afowo formation of Early to Middle Miocene age (Billman, 1976) is subdivided into a lower and an upper units being separated by an unconformity named Mid Miocene Unconformity (H2) which is easily picked both by seismic data and well logs. The basal limit of Afowo formation is picked by seismic horizon (H3) and the lower Afowo unit is described as a light grey siltstone grading upwards to fine grained sandstone. The upper Afowo unit is a sequence of grey brown soft, sticky and silty clay interbedded with friable, coarse-grained sandstone with glauconite, pyrite and shell debris. The interbedded sands have resulted from turbidity currents. The depositional environment is interpreted as marine, outer sublittoral to upper bathyal well oxygenated environment;

- the Pliocene to Recent Benin-Ijebu formation is the uppermost units of Offshore Benin Basin. The units consist of marine shelf sands and become coarser grained toward the top. They also include argillaceous sandstone and siltstone and shale. The stratigraphic succession is capped with very young marine shelf sediments that are prograding southwards. Sediments transport was from the north and rapid sedimentation rates initiated growth faults that sole out in most cases in the Araromi shale (Elvsborg and Dalode, 1985).

Thus, we can indicate that during the post-rift stage, a depositional hiatus from the late Eocene through the Oligocene led to a major unconformity between the Eocene Imo, Oshoshun and Miocene Afowo formations (Fig. 5, 6). A second Miocene unconformity came and separated the lower and upper members of the Afowo Formation.

As a result, the generalized tectono stratigraphic chart of the Offshore Benin Basin can be represented as follow in Figure 6.

During burial processes the lithological characteristics of the formations encountered in the Benin offshore have changed and rocks have acquired particulars petroleum specifities.

\subsection{Petroleum Specificity of the Formations}

Ise Formation (Neocomian section)

In the OBB, the entire Ise formation thickness and chemicals analysis are needed to fully evaluate its petroleum specifities. In Aje field of Western Nigeria, chemical analysis of shale 


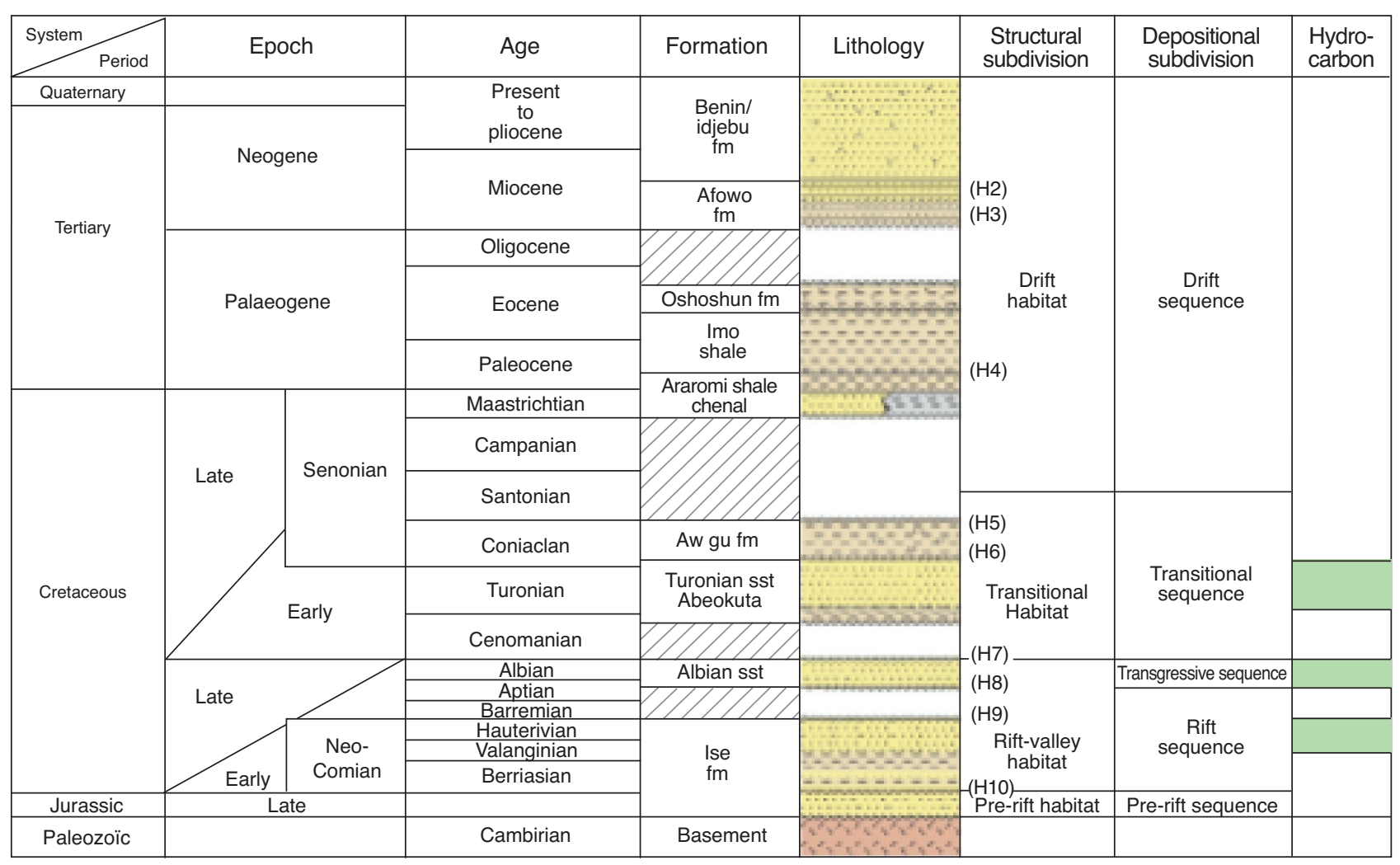

Figure 6

Generalized stratigraphy of the Offshore Benin Basin (Brownfield and Charpentier, 2006 modified).

samples from the upper part of Ise formation (Ise-2 well) show that they contain Type I kerogen, with Total Organic Carbon (TOC) contents as much as $4 \%$. The richest sourcerock intervals have hydrogen index (HI, mg (milligrams) hydrocarbon/g (grams) organic carbon) greater than 500 (Brownfield and Charpentier, 2006). Lower Cretaceous lacustrine strata in oil window are identified as far west as the Ivory Coast Basin and may include similar source rocks (Elvsborg and Dalode, 1985; Abacan-Addax Consortium, 1998). In Seme field, sandstones units with favorable reservoir characteristics have been encountered below the "Albian sandstone" (wells DO-1; DO-D2A; Seme 9 and Seme 10) and identified as from Ise formation. Average porosities of these sandstones are in range of $11 \%$ to $13 \%$.

\section{Albian Formation}

Shales units are present and increase away from coast. Geochemical analysis of 48 samples of Albian shales, gave an average value of $2.91 \%$ TOC. In Seme10 TOC's average is around $1.6 \%$, Hydrocarbon Indices (HI) average is 260 and kerogen are generally 20-70\% sapropelic (IPL, 1991). RockEval (RE) studies pointed out for the well Seme 11 (BeicipFranlab, 1994) gave the following results: TOC: fair to good
(0.5-3.4\% with an average of $2.1 \%) ; \mathrm{S}_{2}$ : poor to good (0.7-5.3 kg HC/t. rock, with an average of $2.8 \mathrm{~kg} \mathrm{HC} / \mathrm{t}$. rock); HI: weak to fair (90-155) and OI (Oil Indice): weak (5-25). Source rocks are likely to be mature in narrow kitchen sub-parallel to the coast. Organic matter is of Type III. However, in consideration of high maturity level of samples, one can't exclude the presence of organic matter of type II before maturation.

For the most important unit, the Albian sandstones unit, average of porosity values is in the range of $13-14 \%$.

\section{Abeokuta Formation}

In this formation, dark Cenomanian shales units reach 10-20\% of sandstones thickness which is over $600 \mathrm{~m}$. Chemical analysis of two samples of Cenomanian shales gave respectively 4.2 and $7.1 \%$ of TOC with HI values of 324 and $531 \mathrm{mg} \mathrm{HC} / \mathrm{g}$ TOC. The Turonian sandstones unit has porosity $20 \%$ and permeability 150 millidarcys $(\mathrm{mD})$ (Beicip-Franlab, 1994).

\section{Awgu Formation}

Chemical characteristics of the formation are following: TOC of 2.4\%; $\mathrm{S}_{2}$ of $13 \mathrm{~kg} \mathrm{HC} / \mathrm{t} ; T_{\max } 440^{\circ} \mathrm{C}$ and $\mathrm{HI}$ of $476 \mathrm{mg} \mathrm{HC} / \mathrm{g}$ TOC. The kerogen is of Type II with equivalent PRV of $0.7 \%$. 

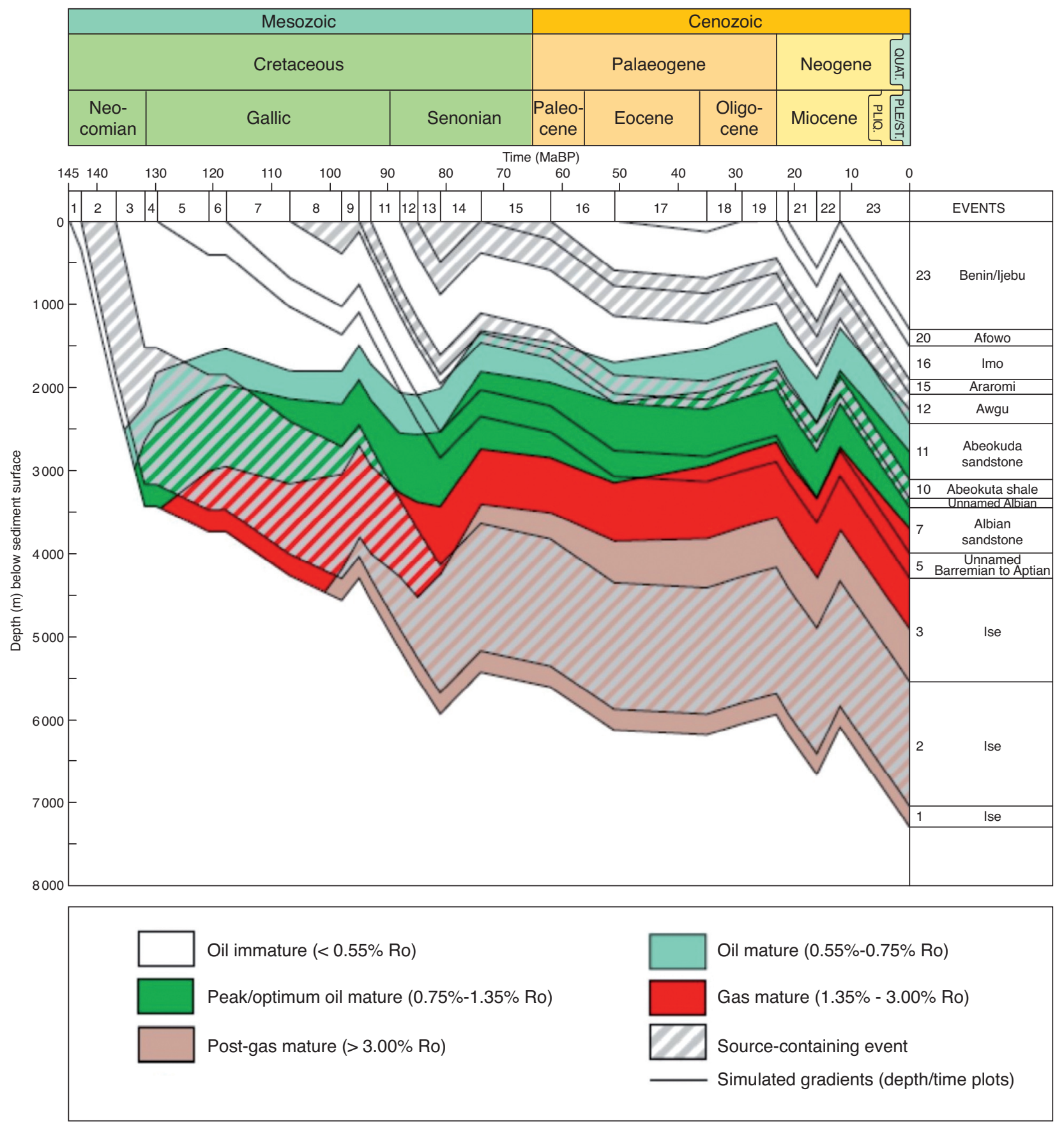

Figure 7

Burial history of Offshore Benin Basin with indication of time-depth maturity level of source rocks intervals (SAPETRO, 2010).

\section{Araromi Formation}

Rock-Eval analysis of samples catched from depth 1630-1810 m in Seme-11well (Beicip-Franlab, 1994), point out an average $\mathrm{S}_{2}$ of $20 \mathrm{~kg} \mathrm{HC} / \mathrm{t}$ rock and an average TOC of $4.4 \%$.

The organic matter is essentially of Type II. South Atlantic Petroleum studies (SAPETRO, 2010) concerning samples of
$\mathrm{S}-1$ well indicate that the TOC reaches $5 \%$ and $\mathrm{HI}$ is about $476 \mathrm{mg} \mathrm{HC} / \mathrm{g}$ TOC. The kerogen is of Type II and Type II-III.

\section{Imo Formation}

The Paleocene to Eocene Imo shale (Fig. 6) contains Type II and Type II-III kerogen with TOC contents ranging from 2 to 
more than $5 \mathrm{w} \%$. The formation is immature in the Dahomey Embayment.

Some geochemical characteristics concerning samples of S-1 well and related to the shale formations of Maastrichtian to Miocene age (Araromi, Imo, Oshoshun and Afowo), are pointed out in Figure 7. Arising from Rock-Eval pyrolysis, similar geochemical results were obtained with Maastrichtian to Eocene sediments of the eastern Dahomey basin (Aje-1 well - southwestern Nigeria). In this region, the Total Organic Carbon (TOC) shows a range from 0.01-3.55 wt $\%$. This indicates that the organic matter is low to adequate, particularly within the dark shaly interval of Araromi and Afowo formations in Aje-1 well. $T_{\max }$ ranges from $359^{\circ} \mathrm{C}$ to $465^{\circ} \mathrm{C}$ and indicate thermally immature to marginally mature sediments, while calculated vitrinite reflectance is $0.27 \%$ to $1.21 \%$ (Nton et al., 2009).

\section{PETROLEUM SYSTEMS OF THE OFFSHORE BENIN BASIN}

The Offshore Benin Basin includes several potential source rocks, many reservoir rocks and a variety of potential trapping mechanisms, some of which have a significant potential. Oil and gas occurrences are concentrated in Cretaceous reservoirs. At least two Petroleum Systems (PS), with unlike concepts plays, exist in the OBB:

- the Upper Cretaceous PS consisting of Albian to Coniacian marine and terrestrial source rocks and Cretaceous reservoir rocks;

- the Lower Cretaceous PS, consisting of Lower Cretaceous lacustrine source rocks and Lower Cretaceous reservoir rocks.

\subsection{Hydrocarbons Source Rocks and Maturation}

Maturation model utilizing Lopatin Time Temperature Index (denoted TTI) was used to calculate the theoretical thermal maturity of source rocks in Seme field (Lopatin, 1976). This model which describes quantitavely the relationship between thermal history and organic maturity, accounts only for the burial history and assumes a background constant geothermal gradient. The model therefore neglects the feedback effect of the sedimentary process itself on the local thermal gradient, where cool sediments are laid down upon a background geothermal gradient in the basement rocks. This model assumes that the maturation rate is exponential in temperature and linear in time for a particular interval of temperature and time-both are reasonable assumptions (Waples, 1980; Palumbo et al., 1999).

Empirically, the model is defined by:

$$
T T I=\sum_{n_{\min }}^{n_{\max }} r_{n} \Delta t_{n}
$$

with $\Delta t_{n}$, time interval (in Ma) that the rock spent in the $n_{t h}$ temperature interval, usually split into $10^{\circ} \mathrm{C}$ independent geothermal gradient bands; $n_{\min }$ and $n_{\max }$, minimum and maximum values of the index $n ; r$, arbitrary number describing the exponential dependence. After empirical calibration tests, the optimum value for the factor $r$ is found to be equal to 2 (Waples, 1980).

Typically, hydrocarbons are produced for $15<T T I<160$. After calibration, this Time-Temperature Indexes (TTI) interval corresponds to a range $0.65<R_{\mathrm{o}}<1.35$ for the oil generative window determined by the vitrinite reflectance technique (Tissot et al., 1980; Perrodon, 1980; Sokolov and Foursov, 1983; Abrikossov and Goutman, 1986; Palumbo et al., 1999).

In the Offshore Benin Basin, proven potential source rocks which have produce oil are shales sequences of Ise, Albian, Abeokuta and Awgu formations. Oil seeps in outcrops of Upper Cretaceous tar sands in the onshore area of the Dahomey Embayment (tar sands of Sakete-Benin and western Nigeria) are interpreted to be sourced by Neocomian lacustrine strata of Ise formation, such as were drilled into Ise-2 well situated eastwards of the Seme oilfield in western Nigeria (Brownfield and Charpentier, 2006). Owing to limited drilling data and samples studies, we cannot actually point out the thickness of shales units of this formation. However, data from Aje field allow us to deduce that Ise formation contains potential source rocks in the deep Benin offshore.

The deposition of Albian shales units coincides in time with the anoxic conditions and black shale deposition that took place in Southern Atlantic basins during Mid-Cretaceous time (Brownfield and Charpentier, 2006). Shales in such settings tend to be organic rich and oil prone (Tissot et al., 1980). Seismic data indicate that Albian and Aptian source rocks may be more present in deep water but are mainly sandstones on the basin shelf. Shale content of Abeokuta formation increases away from coast (SAPETRO, 2010). Although the shale beds are relatively thin within the predominantly sandy succession of Abeokuta formation, the whole thick of the formation give possibility to indicate that its shales sequences are potential source rocks in the OBB. Rock-Eval analysis of samples from core in Seme-9 well (Beicip-Franlab, 1994), indicate that the Awgu formation is a good potential source rocks within the OBB. Currently, the formation continues to generate oil.

The Araromi formation unit covers most of the Beninian shelf. Unfortunately, the thickness of the formation generally did not exceed $100 \mathrm{~m}$, except in three depocenters in the eastern part of the basin where it exceeds $600 \mathrm{~m}$. Arising from available data and previous studies, it can be deduce that Araromi formation is very a good source rock but immature to slightly mature, with prospect to generate oil rather than gas at appropriate maturation. Araromi oil which should be lighter than Albian and Abeokuta oil wasn't encountered in wells. The Paleocene to Eocene Imo shale (Fig. 8) is a good source rock but it completely immature within the OBB. 


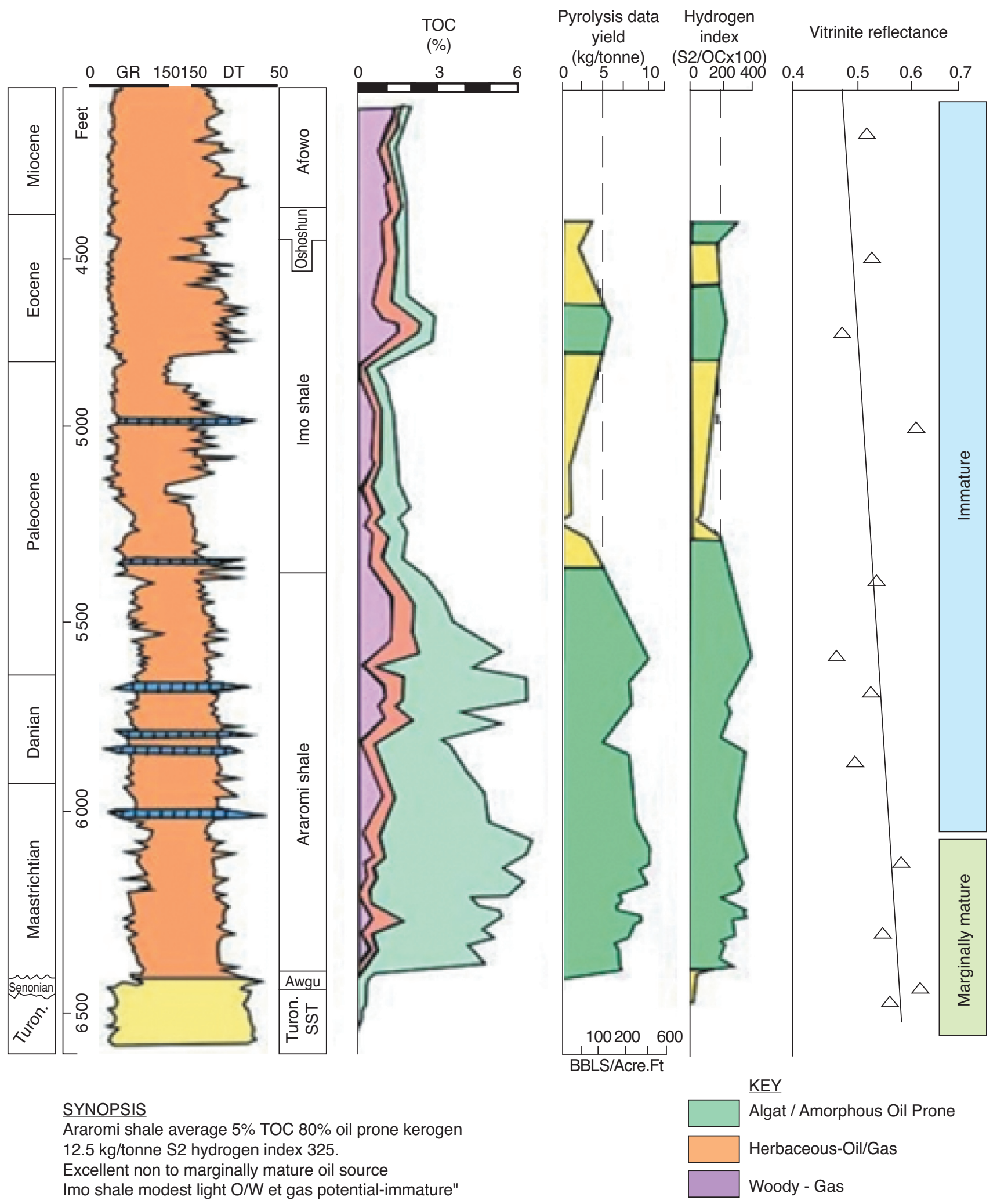

Figure 8

Geochemical summary of Maastrichtian-Miocene sequence (Beicip-Franlab, 1994, modified). 
A global source rocks maturity model basing on Petrel Software was presented by a research team of SAPETRO. On this model, Time Temperature Index (TTI) and vitrinite reflectance values are matched to indicate, on a burial history plot of the basin, the progressive maturity level of containing source rocks intervals (Fig. 7). The vitrinite reflectance technique, a quantitative optical measure of the degree of maturation, was widely used to estimate the source rocks maturation and hydrocarbon generative windows within the OBB. The results, expressed by definition of equal-reflectance lines, point out that the Ise formation has past the oil generation window in Senonian and is now over-mature $\left(R_{\mathrm{o}}>3 \%\right)$. The Albian (unnamed Albian) and Abeokuta (Abeokuta shale 10) shales reach the maturity level of oil generation Eocene and hydrocarbon (gas for Albian source rocks and oil for Abeokuta one) generation may be active to the present. Oil generation started in Pliocene for the Awgu formation.

\subsection{Reservoir Rocks}

At least proven (Ise, Albian and Turonian) reservoirs horizons were highlighted in this offshore basin. Reservoir rocks are mostly Cretaceous turbidites sandstones with minor potential limestone units. Stratigraphic units that contain proven reservoirs in the shallow-water discoveries are mainly late syn-rift Albian sandstones and transitional Cenomanian to Turonian marginal marine and turbidites clastics rocks.

In Seme field terminology, the upper part of the Albian reservoir rocks is defined as Zone 3 that tested oil in DO-1 well and the lower part named Zone 4 has proved to be gas and oil bearing. Cenomanian to Turonian reservoir rocks are generally simple anticline structures delineate by faults. South of the Seme field, the Turonian sandstones to Cenomanian may be eroded by the Araromi formation erosive channels (Fig. 4). The downslope projections of deltas that were formed at that time would be prospective for turbidite channel and ponded turbidite sandstone reservoirs. In general, reservoirs in the transitional habitat are likely to be of better quality than those in the syn-rift habitat. Oils extracted from "Albian sandstones" and "Turonian sandstones" are not the same. Albian Oil tested from Fifa-1 well (Block 4) has $42^{\circ}$ API while Turonian oil tested in 5 wells of Seme field has $22^{\circ}$ API and is little charged in sulfurs $(0.35 \%)$.

Seismic data indicate that a thick Lower Cretaceous syn-rift section in the offshore part of the Benin Coastal Basin contains sandstone reservoir units deposited in fluvial to deltaic environments (Elvsborg and Dalode, 1985; SAPETRO, 2010). Lithological changes are large both in time and space. Similar reservoir rocks should also be present in the Keta Basin below the mid-Albian unconformity (Kjemperud et al., 1992). These possible reservoir rocks could be more present in the deep-water part of the basin in the form of detached sandstone units resulting from ponded turbidite sands behind transpressional structures (see Fig. 5). Recent seismic data indicate that Tertiary section has fewer reservoirs than the Cretaceous section in the Dahomey Embayment. Some slope fans have been identified in the Araromi shale in the overlying section above the regional Maastrichtian unconformity (Fig. 5). The Araromi sandstone unit (Fig. 5, 6) has been interpreted as a slope fan in the offshore Benin Basin.

\subsection{Hydrocarbon Generation and Migration}

In the Offshore Benin Basin hydrocarbon generation began in late Cretaceous time and may be active to the present (Amelina, 1984). The most important hydrocarbon generation within the Dahomey Embayment is from the upper Albian, Cenomanian and Awgu source rocks, which are distributed throughout the entire offshore part of the region. These strata are expected to increase in thickness and source rock quality into deep water. The main area of hydrocarbon generation is interpreted to exist eastward to the Niger Delta. This possible oil kitchen is only present in the deep-water parts of Dahomey Embayment where the source rocks have reached a temperature of at least $100^{\circ} \mathrm{C}$ and a vitrinite reflectance $\left(R_{\mathrm{o}}\right)$ more than 0.6\% (MacGregor et al., 2003). Hydrocarbon generation started in the Late Cretaceous for the Albian to Cenomanian source rocks and continues to the present.

The hydrocarbon generation history graph obtained after analysis of Albian sample (Seme-1 well; source rocks No. 7; organic matter No. 2), shows the gap time, amount of generated hydrocarbons and residue (mg HC/g TOC) (Fig. 9).

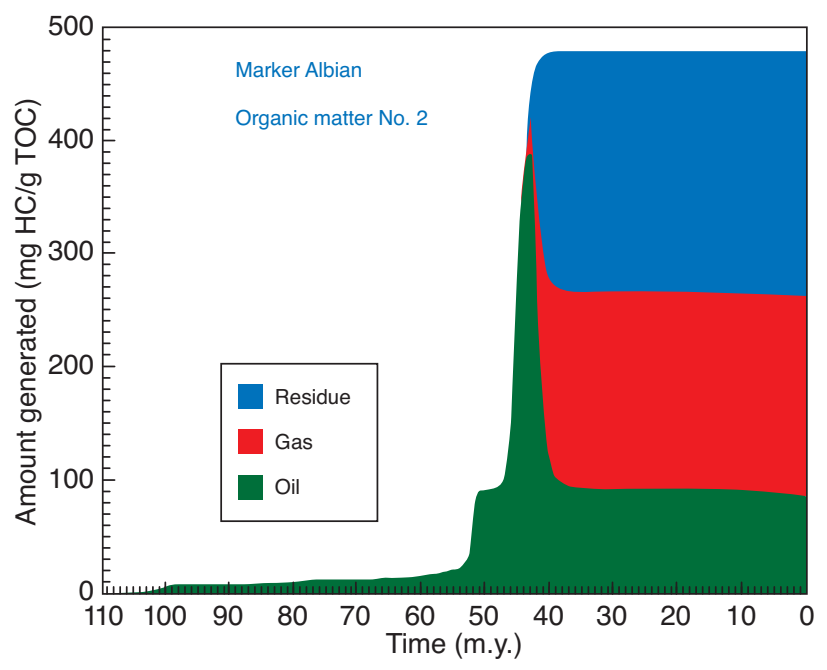

Figure 9

Hydrocarbon generation history for Albian shales (BeicipFranlab, 1994). 
This maturation model indicates that the "Albian sandstone" maturation levels adequate for petroleum generation were reached in Eocene. Currently, in the Offshore Benin Basin, Albian source rocks are expected to contain gas-prone Type III kerogen similar to the one identified in Tano and Ivoirian basins (MacGregor et al., 2003).

A single Seme-1 well model of hydrocarbons and residue generation ratio based on depth and geochemical characteristics of Albian to Benin-Ijebu formations is shown in Figure 10.

For the Turonian and Coniacian source rocks, hydrocarbon generation possibly started in the early Tertiary and also continues to the present. Araromi oil which should be lighter than Albian and Abeokuta oils wasn't encountered in Benin offshore. Some areas of hydrocarbon generation related to Lower Cretaceous lacustrine source rocks are present in the Dahomey Embayment (Haack et al., 2000; MacGregor et al., 2003). Taking into account the maximum depth of drilled Ise formation within the OBB, a model indicates that the upper part of the Ise passed the main oil generation window in Paleocene. For the deeper part, the main oil generation window occurred probably at Late Cretaceous time.

The hydrocarbon migration from late Cretaceous and Early Tertiary source rocks should occur during Late Tertiary times. Oils extracted from various field within the basin were generated in late Cretaceous to Miocene time and migrated in tertiary time from south and south west after the structures were already established. Migration was either directly from adjacent source rocks or upward along faults from deeper sources. The lower parts of the Araromi shales have reached the mature stage but generation and migration still take place. The Araromi formation is partially mature and is presently at the beginning of the oil generation window ( $\sim 7$ eq. PRV).

\subsection{Hydrocarbon Traps and Seals}

Both structural and stratigraphic traps are present in the OBB. Structural traps are associated with each main tectonic stage. Syn-rift anticlinal traps (Fig. 5), detected only from seismic data and as yet untested, are associated with the terminations of regional fracture zones in the offshore parts of the Dahomey Embayment (SAPETRO, 2010). All stratigraphic traps (unconformity with shale) forming seal on the top of reservoir rocks were shaped before the end of the Cretaceous. The sratigraphic traps envisaged for the Maastrictian-Daanian sequence enveloped in shales that may provide seal as well as source rocks. Moreover, trap adjustment occurred as a result of basin ward tilting in both Late Cretaceous and Tertiary times following continental break-up. Seismic data indicate that undrilled channel-erosion traps are commonly associated with the regional Oligocene unconformity from Benin westward, in the deep-water part of the Dahomey Embayment. Ponded turbidite traps are observed as detached sandstone bodies in the Benin Basin, where stratigraphic trapping and updip seals are the critical factors in defining potential targets.

Seals are marine shales and shale-filled channels with minor fault-related ones. Seals associated with rift-valley habitat are formed by both shales and faults, whereas seals associated with transitional habitat are generally shales (Fig. 5, 6). Seals of Turonian reservoirs are generally assume by shales of Awgu formation and also by interbedded shales layers within Abeokuta formation. The Awgu formation is limited at the top by Senonian unconformity and at the base by the seismic marker H6. The Awgu formation is present on the entire shelf except for localized areas in the vicinity of the

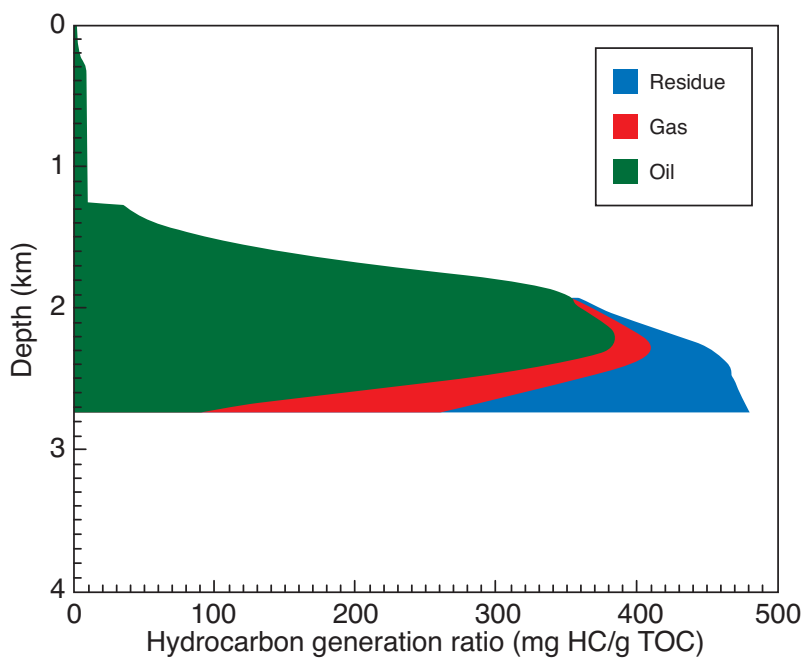

Figure 10

Graph of a single model of hydrocarbon generation (Amelina, 2006).

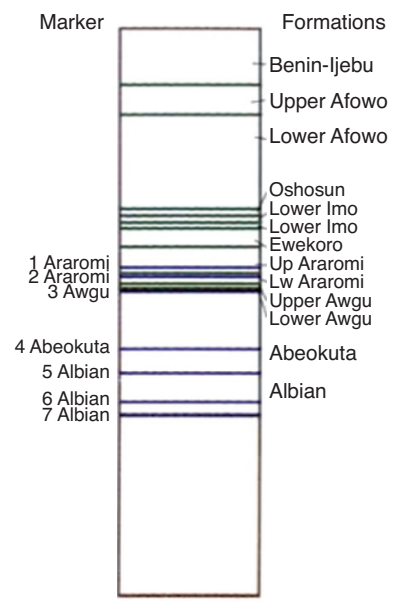


Seme field. The present distribution of the Awgu formation is controlled by the Senonian unconformity, a regional low sea level sand feature of Santonian to Lower Campanian age, which in places has eroded through the entire Turonian section. Seaward, the Araromi and Imo formations cut the Turonian reservoir. That means that the Maastrichtian and Paleocene regional unconformities also clearly play the role of seal on the slope and may be in deepwater.

The Lower Cretaceous Ise formation traps may have been source from lacustrine shales of the same formation. Its thickness leaves the possibility of the long interval with oil and gas expulsion. However, early generated hydrocarbons may have been lost before the formation of a seal on the top of the unconformity traps.

In summary, we can specify that several potential source rocks, many reservoir rocks and a variety of trapping mechanisms, some of which have a significant potential are present in the Offshore Benin Basin. Data related to recognize elements (source rocks and reservoir rocks) and processes (hydrocarbon generation, migration and traps formation) can be chart in petroleum systems. Thus, two Petroleum Systems (PS), with unlike concepts plays, exist in the Offshore Benin Basin:

- the Upper Cretaceous PS consisting of Albian to Cenomanian marine and terrestrial source rocks and Cretaceous reservoir rocks;

- the Lower Cretaceous PS, consisting of Lower Cretaceous lacustrine source rocks and Cretaceous reservoir rocks.

\section{Upper Cretaceous Petroleum System}

The Upper Cretaceous PS was defined in the entire Dahomey Embayment (see Fig. 1). Only this well-known PS was considered for assessment, because:

- it is the most extensive;

- current exploration and production are mostly limited to this system.

The principal source rocks for the Cretaceous PS are Albian, Cenomanian and Turonian marine shales with Type II; Type II-III oil-prone kerogen and Type III terrestrial kerogen. The Coniacian Awgu Formation and the Maastrichtian Araromi Shale (Fig. 6) contain marine source rocks in Benin offshore. These source rocks contain Type II and Type II-III kerogen with TOC contents ranging from 2 to more than $5 \mathrm{wt} \%$. The area of the original deposition was from the northwestern extension of the Niger Delta westward to the Keta Basin (Haack et al., 2000). Hydrocarbon generation started in the Late Cretaceous for the Albian to Cenomanian source rocks and continues to the present. For the Turonian and Coniacian source rocks, hydrocarbon generation possibly started in the early Tertiary and also continues to the present. Reservoir rocks are mostly Cretaceous turbidite sandstones with minor potential limestone units. In Seme field nine (09) wells have produced each an average of 3000 BOPD (Barrels of Oil Per Day). In the nearby Aje field, this average is about 8000 BOPD. Migration was either directly from adjacent source rocks or upward along faults from deeper sources. The traps include pre-rift traps related to fault blocks, syn-rift structural and stratigraphic traps and post-rift stratigraphic traps. Seals are marine shales and shale-filled channels with minor fault-related seals.

An events chart for this total petroleum system graphically portrays the ages of the source, seal and reservoir rocks, as well as the timing of trap development and generation, migration and preservation of hydrocarbons and the critical moment is shown in Figure 11. The critical moment is defined as the beginning of hydrocarbon generation and migration.

\section{Lower Cretaceous Petroleum System}

Only limited exploration information is available for the Lower Cretaceous PS. Lower Cretaceous PS oils have only been identified in Upper Cretaceous tar sands and oil seeps at Cape Three Points (western Ghana) and in the Dahomey Embayment (Benin and western Nigeria).

Currently, it is assumed that upper Albian reservoirs in Seme and Aje fields are sourced from Ise formation shales, because downward migration from Upper Cretaceoussourced oils seems unlikely. Hydrocarbon generation most likely began in the Early Cretaceous and may have continued into the early Tertiary. The Lower Cretaceous PS was defined because lacustrine source rocks and sandstones reservoirs deposited in early grabens have been recognized in the entire Dahomey Embayment (from Aje oilfield westwards), as evidenced in wells test and by the presence of lacustrine oils from Upper Cretaceous tar sands and seeps in areas west of Cape Three Points in western Ghana, as well as in Sakete region of Benin Republic. Oil from Ise formation has been tested in the OBB (Ouidah-1 well in Block 3; Porto-Novo well in Block 2) and in Lome field (Lome-1 well) (Fig. 2, 6). In Lome Field, Ise sandstones units have produced in test 500 BOPD. Although Ise formation is not yet productive in the OBB, Pendencia sands (Ise equivalent) in Potiguar Basin (Eastern Brazil) are productive. Similar productive reservoir rocks are also present in the Keta Basin below the midAlbian unconformity (Kjemperud et al., 1992). Concerning the Albian reservoirs, oil tests from five wells of Seme field were positive. In two of them, the test gives over $1000 \mathrm{BOPD}$ along with $90 \mathrm{~m}$ of potential oil pay in DO-C1 well.

Events charts for potential Lower Cretaceous PS graphically portray the ages of source rocks, reservoir rocks and seal, as well as the timing of generation, migration, trap development, preservation of hydrocarbons and the critical moment (Fig. 12). The critical moment is defined as the beginning of hydrocarbon generation and migration. This petroleum system is few documented in reports and not assessed in the OBB because of data lack. 


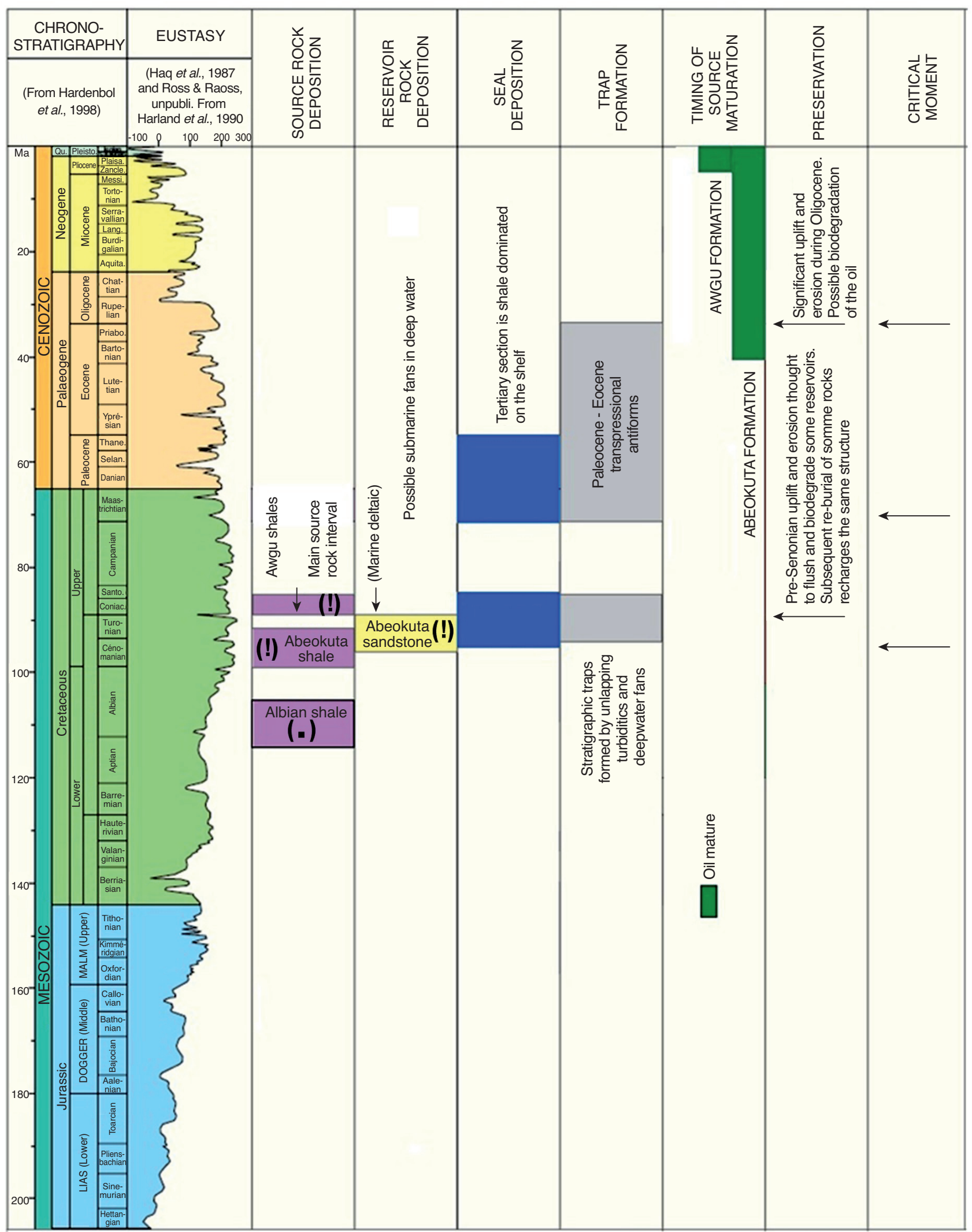

Figure 11

Well-known Upper Cretaceous Petroleum System of Seme oilfield (SAPETRO, 2010).

Nomenclature for source rocks and reservoirs: (!) known; (.) hypothetical. 


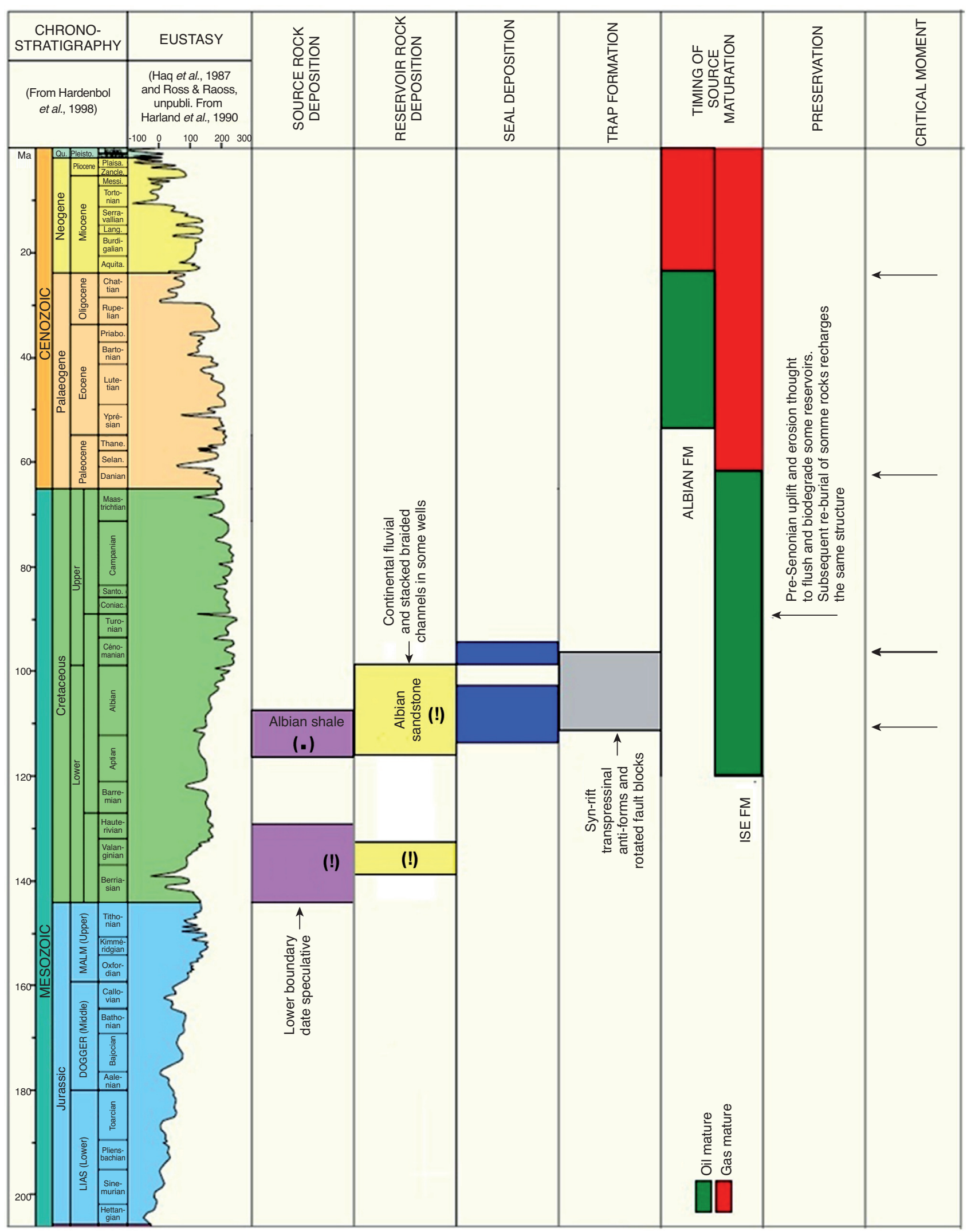

Figure 12

Lower Cretaceous Petroleum System of Seme oilfield. Nomenclature for source rocks and reservoirs: (!) known; (.) hypothetical. 


\section{CONCLUSION}

The tectonostratigraphy development and the history of the formation of the total Petroleum Systems of the Offshore Benin Basin are summarized in events charts (Fig. 11, 12). Rocks within the petroleum system are from Lower Cretaceous to Paleocene in age. Most of the petroleum is sourced from the Awgu Formation, with smaller amounts generated from the mature shale beds of Ise, Albian and Abeokuta Formations. Hydrocarbon generation within the Offshore Benin Basin began in Late Cretaceous and continues to the present. Two Petroleum Systems exist in the Offshore Benin Basin:

- the proven Upper Cretaceous Petroleum System which consists of middle Albian to Coniacian Type II, II-III and III oil-prone kerogen and Type III gas-prone kerogen and Cretaceous reservoirs. Cretaceous marine mudstones and shales are the primary seals. Reservoirs are sandstones throughout the Abeokuta Formation;

- the Lower Cretaceous Petroleum System, consisting of proven Lower Cretaceous lacustrine source rocks (Type I kerogen) and reservoir rocks. Reservoirs are below currently producing Turonian reservoirs and, in the distal portions of the basin, may include sands as well as turbidite sands within Albian Formations. Although this Petroleum System is considered to have hydrocarbon potential, it is not yet assessed. It is why this Petroleum System is still considered as hypothetical within Benin offshore.

Exploration works are now expanding especially in deeper water. The deep-water part of the Offshore Benin Basin is underexplored and contains many potential prospects emphasized by 3D seismic of Petroleum Geo-Services (PGS). Structural traps have been the most favourable exploration target; however, stratigraphic traps are likely to become more important targets in distal and deeper portions of the OBB.

\section{ACKNOWLEDGMENTS}

The authors thank the authorities of the Ministry in charge of Petroleum and Mining Research of Benin Republic for their collaboration which were very useful for the redaction of this paper and greatly improved the text.

\section{REFERENCES}

Abacan-Addax Consortium (1998) Ise Hydrocarbon Potential Benin Offshore Block 1, Report, 113 p.

Abrikossov I., Goutman I. (1986) Géologie du Pétrole: Généralités, Prospection, Exploitation, Ed. Mir, Moscou.

Almeida F.F.M., Black R. (1967) Comparaison structurale entre le Nord-Est du Brésil et l'Ouest Africain, Symposium on Continental Drift, Montevideo, Uruguay, 16-19 Oct.

Amelina S. (1984) Benin Basin Evaluation, Reports SAGA Petroleum, Vol. I, 79 p.; Vol. II, 259 p.
Amelina S. (2006) Geology of Seme Oilfield, Report BeicipFranlab, 37 p.

Aslanian D., Moulin M., Olivet J.-L., Unternehr P., Matias L., Bache F., Rabineau M., Nouzé H., Klingelhoefer F., Contrucci I. and Labails C. (2009) Brazilian and African passive margins of the Central Segment of the South Atlantic Ocean: Kinematic constraints, Tetonophysics (Special Issue: Role of magmatism) 48, 98-112.

Beicip-Franlab (1994) Etude Géologique et Evaluation des Réserves du Champ de Sèmè, Rapports Vol. I, 157 p. et Vol. II, 128 p.

Billman H.G. (1976) Offshore stratigraphy and Paleontology of the Dahomey Embayment, West Prepared for the 7th African Micropaleontological Colloquium, Ile-Ife, Nigeria, 1976.

Billman H.G. (1992) Offshore stratigraphy and Paleontology of the Dahomey Embayment, West African N.A.P.E. Bulletin, Vol. 7 (2), 121-130.

Brownfield M.E., Charpentier R.R. (2006) Geology and total petroleum systems of the West-Central Coastal Province (7203), West Africa, U.S. Geological Survey Bulletin 2207-C, 52 p.

Bumby A.J., Guiraud R. (2005) The geodynamic setting of the Phanerozoic basins of Africa, J. Afr. Earth Sci. 43, 1-12. doi:10.1016/j.jafrearsci.2005.07.016.

Burke K., Dessauvagie T.F.J., Whitman A.J. (1971) Opening of the Golf of Guinea and geological history of the Benue depression and Niger delta, Nature Phys. Sci. 233, 38, 51-55.

Chierici M.A. (1996) Stratigraphy, paleoenvironments and geological evolution of the Ivory Coast - Ghana basin, Jardiné S., de Klasz I., Debenay J.-P. (eds), Géologie de l'Afrique et de l'Atlantique Sud, 12 e Colloque de Micropaléontologie Africaine, $2 e$ Colloque de Stratigraphie et de Paléogéographie de l'Atlantique Sud, Angers, France, 16-20 juillet 1994, Recueil des Communications: Pau, Elf Aquitaine, Mémoire 16, 293-303.

Dumestre M.A. (1985) Northern Gulf of Guinea shows promise, Oil Gas J. 83, 18, 154-165.

Eagles G., Konig M. (2008) A model of plate kinematics in Gondwana breakup, Geophys. J. Int. 173, 703-717.

Elvsborg A., Dalode J. (1985) Benin hydrocarbon potential looks promising, Oil Gas J. 11, 126-131.

Guiraud R., Maurin J.-C. (1992) Early Cretaceous rifts of western and central Africa - An overview, Tectonophysics 213, 153-168.

Haack R.C., Sundararaman P., Diedjomahor J.O., Xiao H., Gant N.J., May E.D., Kelsch K. (2000) Niger Delta petroleum systems, Nigeria, Mello M.R., Katz B.J. (eds), Petroleum systems of South Atlantic margins, Am. Assoc. Petroleum Geologists Mem. 73, 213-231.

Haq B.U., Hardenbol J., Vail P.R. (1987) Chronology of fluctuating sea levels since the Triassic (250 million years ago to present). Science 235, 1156-1167.

Hardenbol J., Thierry J., Farley M.B., Jacquin Th., de Graciansky P.-C. and Vail P.R. 1998. Mesozoic and Cenozoic sequence chronostratigraphic framework of European basins, in: MesozoicCenozoic Sequence Stratigraphy of European Basins, SEPM Special Publication (Tulsa), 60, pp. 3-13.

Harland W.B., Armstrong R.L., Cox A.V., Craig L.E., Smith A.G., Smith D.G. (1990) A geological time scale, 1989. Cambridge Earth Science Series. Cambridge University Press, Cambridge, 263 p.

Hessouh M., Marcos I., Pereira J.-J., Farhangui H.J. (1994) Hydrocarbon Prospects for Exploration and Production, Report, 88 p.

International Petroleum Limited (IPL) (1991) Offshore Benin Blocks 1 and 2: Technical Evaluation, Report, 57 p.

Jan Duchene R. (1998) Geology and sequence stratigraphy of the Benin basin, Report ABACAN, 68 p. 
Kaki C., Oyede L.M., Laibi R.A., Yessoufou S. (2001) Influence de la dynamique sédimentaire et structurale sur la formation des réservoirs détritiques du Crétacé dans le bassin sédimentaire côtier (RESO-BSC) du Bénin (Golfe du Bénin, Afrique de l'Ouest), Symposium sur la "redéfinition du socle du bassin sédimentaire côtier du Bénin”, Actes, pp. 213-237.

Kjemperud A., Agbesinyale W., Agdestein T., Gustafsson C., Yükler A. (1992) Tectono-stratigraphic history of the Keta Basin, Ghana with emphasis on late erosional episodes, $1^{\text {er }}$ colloque de stratigraphie et de paléogéographie des bassins sédimentaires ouest-Africains et $2^{e}$ Colloque Africain de micropaléontologie, Libreville, Gabon, 6-8 Mai, 1991. Elf Aquitaine, Mémoire 13, 55-69.

Kogbe C.A., Mehes K. (1986) Micropaleontology and biostratigraphy of the coastal basins of West Africa, J. Afr. Earth Sci. 5, 1, 1-10.

Le Pichon X., Hayes D.E. (1971) Marginal offsets, fractures zones and the early opening of the South Atlantic, J. Geophys. Res. 76, 6283-6293.

Lopatin N.V. (1976) Historico-genetic analysis of petroleum generation: Application of a model of uniform continuous subsidence of the oil-source bed, Akad. Nauk SSSR, Izv. Ser. Geol. 3, 95-106.

MacGregor D.S., Robinson J., Spear G. (2003) Play fairways of the Gulf of Guinea transform margin, Arthur T.J., MacGregor D.S., Cameron N.R. (eds), Petroleum geology of Africa - New themes and developing technologies, Geol. Soc. London. Spec. Publ. 207, 289 p.

Mascle J. (1976) Le Golfe de Guinée : exemple d'évolution d'une marge Atlantique en cisaillement, Mém. Soc. Géol. Fr. Série 128, 104.

Mascle J., Blarea E., Marinho M. (1988) The shallow structures of the Guinea and Ivory Coast - Ghana transform margins - Their bearing on the equatorial Atlantic Mesozoic evolution, Tectonophysics 155, 193-209.

Moulin M., Aslanian D., Unternehr P. (2010) A new starting point for the South and Equatorial Atlantic Ocean, Earth-Sci. Rev. 98, $1-2,1-37$.
Nton M.E., Ikhane P.R., Tijani M.N. (2009) Aspect of Rock-Eval Studies of the Maastrichtian-Eocene Sediments from Subsurface, in the Eastern Dahomey Basin Southwestern Nigeria, Eur. J. Scientific Res. 25, 3, 417-427.

Omatsola M.E., Adegoke O.S. (1981) Tectonic evolution and Cretaceous stratigraphy of the Dahomey basin, Jour. Min. Geol.18, 1, 130-137.

Palumbo F., Main I.G. and Zito G. (1999) The thermal evolution of sedimentary basins and its effect on the maturation of hydrocarbons. Geophys. J. Int. 139, 248-260.

Perrodon A. (1980) Genèse et répartition des gisements d'hydrocarbures, Géodynamique Pétrolière, Ed. Masson - Elf Aquitaine, Paris, Pau.

SAPETRO South Atlantic Petroleum (2010) Benin Bloc 1 / Seme Petroleum System, Report, 8 p.

Slansky M. (1962) Contribution à l'étude géologique du bassin sédimentaire côtier du Dahomey et du Togo, Thèse, Univ. Nancy, série 59, 165. Mém. BRGM n¹1.

Sokolov V., Foursov A. (1983) Prospections détaillées des Champs de pétrole et de gaz, Ed. Mir, Moscou.

Tissot B., Demaison G., Masson P., Delteil J.R., Combaz A. (1980) Paleoenvironment and petroleum potential of middle Cretaceous black shales in Atlantic basins, Am. Assoc. Petroleum Geologists Bull. 64, 12, 2051-2061.

Tucker J.W. (1992) Aspects of the Tano Basin stratigraphy revealed by recent drill in Ghana, Géologie Africaine, $1^{\text {er }}$ Colloque de stratigraphie et de paléogéographie des bassins sédimentaires ouestAfricains et $2^{e}$ Colloque Africain de micropaléontologie, Libreville, Gabon, 6-8 Mai, 1991. Elf Aquitaine, Mémoire 13, 153-159.

Waples D.W. (1980) Time and temperature in petroleum formation: Application of Lopatin method to petroleum exploration, $A A P G$ Bull. 64, 916-926.

Final manuscript received in June 2012 Published online in December 2012 